\title{
The part of livestock and pets in wolf diet in Lithuania
}

\section{Renata Špinkytė-Bačkaitienė,}

Petras Adeikis

Vytautas Magnus University,

K. Donelaičio St. 58,

Kaunas 44248, Lithuania
Since wolves cause substantial damage to livestock, farmers demand that the wolf population be reduced. Environmental nongovernmental organisations are opposed to this idea, therefore social tensions in the society are rising. The patterns of damage done to livestock were investigated by using data registered in the Biological Diversity Database (BDD) of the State Service for Protected Areas under the Ministry of Environment in the period from 1 January 2019 to 1 December 2021. Wolf diet was analysed by examining the stomach content of hunted wolves and the content of collected scats $(n=132)$. During the analysed period, 1139 cases of wolves attacking livestock were submitted to the BDD. Twenty-eight cases of wolves attacking dogs were submitted to BDD from 1 January 2019 to 1 December 2021. A total of 1167 animals were killed in 2019; 1279 animals were killed in 2020, and 875 animals were killed in 2021 (before 1 December). During the three years analysed, wolves most frequently attacked sheep (60.1-67.4\% of cases annually). In accordance with the data gathered from analyses of the contents of wolves' stomach and scats, remains of domestic animal were found in $6.82 \%$ of all samples.

Keywords: wolf, diet, livestock, dog, damage, attack

\section{INTRODUCTION}

The strongest factor determining the conflict between humans and wolves is the damage that wolves cause to livestock and pets (Álvares, 2011; Chapron et al., 2014; Newsome et al., 2016; Carter, Linnell, 2016). Wolves do substantial damage to livestock, thus farmers demand that the wolf population be reduced. Environmental NGOs (non-governmental organisations) are opposed to this idea; therefore social tensions in the society are rising.

Research shows that the frequency of depredation relates to the abundance and availability

* Corresponding author. Email: renata.spinkyte-backaitiene@vdu.lt of livestock, which is determined by the farming method and the time of year (Nowak, Mysłajek 2004, 2006; Torres et al., 2015; Llaneza, LopezBao, 2015; Ciucci et al., 2018). The species of the most frequently attacked livestock depends on the abundance of the species. Wolves mostly attack sheep in the countries that are mostly oriented towards sheep-farming (Nowak et al., 2005; Iliopoulos et al., 2009; Trbojević et al., 2020), whereas in territories that are high in the number of other livestock, frequently, or in some cases even dominantly, cattle and calves (Jędrzejewski et al., 2002; Capitani et al., 2016), or even goats (Iliopoulos et al., 2009; Petridou et al., 2019) are attacked. 
The aim of this study was to evaluate the role of livestock and pets in wolf diet and to analyse distribution and variability of damage caused by wolves in Lithuania.

\section{MATERIALS AND METHODS}

The patterns of damage done to livestock were investigated by using data registered in the Biological Diversity Database of the State Service for Protected Areas under the Ministry of Environment. The factors for choosing data from this particular database are the following: the data is sufficiently comprehensive, the exact location of the case is marked, and photos proving the case are attached. Data registered from 1 January 2019 to 1 December 2021 were analysed.

Wolf diet was analysed by examining the stomach content of hunted wolves and the content of collected scats. In total, 132 samples were analysed. The data was collected across various parts of Lithuania (2019-2021 time span). The analysis of food left-overs in the laboratory was done by using the standard method of drying the content and washing it through a sieve (Lockie, 1959; Goszczynski, 1974; Litvaitis et al., 1996). The remains of the pray, such as hair, nails, bones, teeth, and remains of hooves were dried and weighed by using an electronic scale with 1 gram accuracy (Andersone, 1998; Valdmann et al., 1998; Nowak et al., 2005). A microscopic hair analysis was done by using samples of Teerink (1991), De Marinis and Asprea (2006) and our own sample collection.

Kernel density analysis was used for the distribution of damage evaluation.

\section{RESULTS AND DISCUSSION}

During the period from 1 January 2019 to 1 December 2021, 1139 instances of wolves' attacks on livestock were registered in the Biological Diversity Database of the State Service for Protected Areas under the Ministry of Environment. In 2019, 383 such cases were recorded, 445 cases in 2020, and 311 cases before 1 December 2021 (Table). The number of killed animals came up to 1167 in 2019, 1279 in 2020, and 875 before 1 December 2021.

Table. Cases of wolves attacking livestock submitted to the Biological Diversity Database of the State Service for Protected Areas under the Ministry of Environment, 1 January 2019 to 1 December 2021

\begin{tabular}{|c|c|c|c|c|c|}
\hline Damage period & Cattle & Sheep & Goat & Fallowdeer Red deer & Total \\
\hline Attacks in 2019, number & 110 & 248 & 24 & 1 & 383 \\
\hline Attacks in $2019, \%$ & 28.7 & 64.8 & 6.3 & 0.3 & 100 \\
\hline Animals killed in 2019, number & 134 & 972 & 60 & 1 & 1167 \\
\hline Animals killed in $2019, \%$ & 11.5 & 83.3 & 5.1 & 0.1 & 100 \\
\hline Attacks in 2020, number & 109 & 300 & 31 & 5 & 445 \\
\hline Attacks in $2020, \%$ & 24.5 & 67.4 & 7.0 & 1.1 & 100 \\
\hline Animals killed in 2020, number & 128 & 1077 & 56 & 18 & 1279 \\
\hline Animals killed in $2020, \%$ & 10.0 & 84.2 & 4.4 & 1.4 & 100 \\
\hline Attacks in $2021^{\star}$, number & 102 & 187 & 21 & 1 & 311 \\
\hline Attacks in $2021^{\star}, \%$ & 32.8 & 60.1 & 6.8 & 0.3 & 100 \\
\hline Animals killed in $2021 *$, number & 127 & 665 & 52 & 31 & 875 \\
\hline Animals killed in $2021 *, \%$ & 14.5 & 76.0 & 5.9 & 3.6 & 100 \\
\hline Attacks total, number & 321 & 735 & 76 & 7 & 1139 \\
\hline Attacks total, $\%$ & 28.2 & 64.5 & 6.7 & 0.6 & 100 \\
\hline Animals killed total, number & 389 & 2714 & 168 & 50 & 3321 \\
\hline Animals killed total, $\%$ & 11.7 & 81.7 & 5.1 & 1.5 & 100 \\
\hline
\end{tabular}

Note: ${ }^{\star}$ from 1 January 2021 to 1 December 2021. 
During the three analysed years, wolves most frequently (60.1-67.4\% of cases annually) attacked sheep. When counting killed individuals, sheep comprise an even bigger share of all animals killed by wolves $(76.0-84.2 \%$ of total animals killed annually). Seven cases were registered when wolves attacked fallow deer and red deer kept in enclosures.

The proportion of livestock killed by wolves between 2019 and 2021 (82\% sheep, 12\% cattle) differs from the proportion in 2009-2010 or between 1999 and 2001, where the proportion of killed sheep was much smaller. In 20092010, the share of sheep was $43.4 \%$ and of cattle 48.3\% (Špinkytė-Bačkaitienè, 2012); from 1999 to 2001, the share of killed sheep was $34 \%$ and cattle made up $47 \%$ (Balčiauskas et al., 2002).

In accordance with the data gathered the analysis of the content of wolf stomachs and scats, remains of domestic animals were found in nine cases. This accounted for $6.82 \%$ of all samples $(n=132)$. Sheep remains were found in four (3.03\%) samples of stomach and scat content, cattle remains were found in three (2.27\%) samples, and goat remains were found in one $(0.76 \%)$ sample. A single sample $(0.76 \%)$ of stomach content contained remains of a dog. A similar research regarding wolf diet was conducted between 2004 and 2011: during this period, 2.2\% of the analysed samples $(n=182)$ had remains of domestic animals (Špinkytè-Bačkaitienè, 2012).

As a rule, attacks on livestock were not evenly spread throughout the whole year in the period of 2019-2020 (Fig. 1). Most frequently, animals were attacked in September $(22.2 \%$ of all attack cases), October (19.2\%), and August (18.4\%). However, a significant increase in such cases was observed from May. During the whole grazing period, sheep attacks were 2-5 times more frequent than attacks on other livestock.

During an attack, an average of 1.2 heads of cattle were killed. In $83.5 \%$ of attacks, wolves killed only single head of cattle; however, a case was registered in September when wolves killed seven 3-7-month-old calves during a single attack. In average, 3.7 sheep were killed during each attack. Most frequently, a single sheep was killed during an attack (32.0\%), two sheep during $17.3 \%$ attacks, and three during $15.7 \%$ of attacks. However, more than ten sheep were killed during $6.0 \%$ of attacks. The biggest number of sheep killed was registered in Moletai district in October: 43 sheep were killed during a single attack.

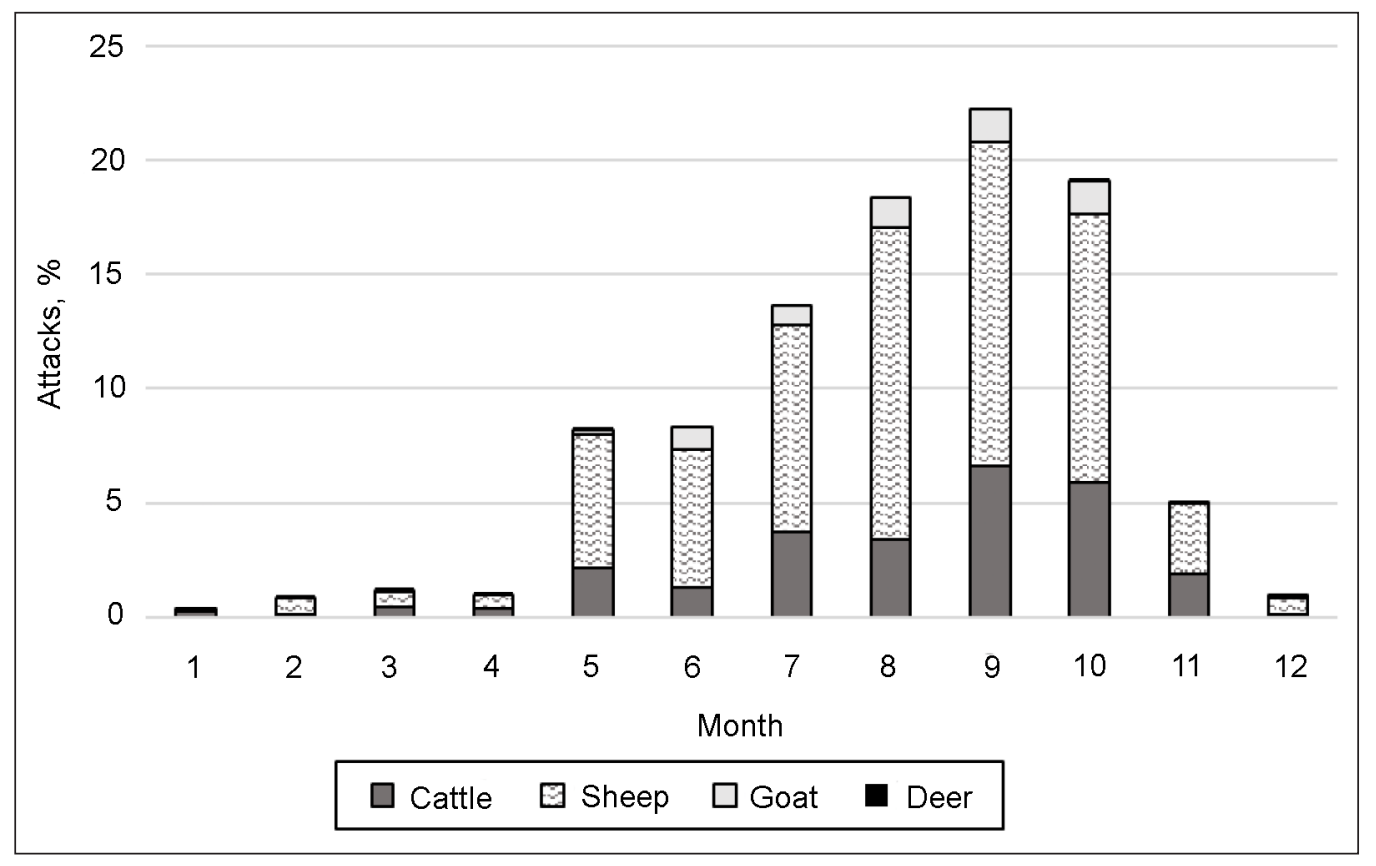

Fig. 1. Number of attacks on livestock throughout the period of 2019-2020, by month 
The cases of wolf depredation on livestock were spread unevenly across Lithuania (Fig. 2), although they cover most districts. As it can be seen from the maps of 2019, 2020, and part of 2021 , the damage done by wolves in each district differs from year to year, therefore it is questionable if it is worthwhile to apply specific wolf population control models tailored to specific districts.

It is not mandatory to register cases when wild predators do damage to pets (dogs); moreover, there are no compensations for such kills and thus gathering reliable information about such cases is problematic. Communication with people in different areas revealed that they knew of specific cases when wolves attacked dogs that were in the surrounding domestic areas. Such information gathered from personal commu- nication leads to a preliminary conclusion that attacks on dogs happen in practically every district in Lithuania and are evidently more frequent compared to the information uploaded to www.biomon.lt. Thirty cases of wolves' attacks on dogs were submitted from 1 January 2017 to 1 December 2021. Most of the attacks on dogs (46.7\%) happened in 2020 ( $n=14) ; 11(36.7 \%)$ attacks were registered in 2021. The rise of registered cases in 2020 and 2021 may be explained by more people being informed about the existing registering system www.biomon.lt. Most frequently $(80.0 \%)$, one dog was attacked, however, there were seven $(20.0 \%)$ cases when two dogs suffered during one attack. Winter accounts for $58.3 \%$ of attacks, although there is data showing that attacks happen during other seasons as well (Fig. 3).


Fig. 2. Damage done by wolves to livestock in 2019, 2020, and part of 2021 (before 1 December), by district. Dark green indicates low damage, red indicates high damage



Fig. 3. Wolf attacks on domestic dogs from 1 January 2017 to 1 December 2021, by month 
Wolves attacking and killing dogs were registered in the following district municipalities: one case in Akmené, Ignalina, Jonava, Kaišiadorys, Kèdainiai, Molètai, Panevėžys, Radviliškis, Širvintos, Švenčionys, Tauragè, and Ukmerge each; two cases in Biržai, Joniškis, Raseiniai, and Šalčininkai each; three cases in Lazdijai district and seven cases in Šakiai district.

The damage done to livestock is the chief reason for the conflict between people and wolves. Every year big losses are experienced (1167 animals killed in 2019, 1279 animals killed in 2020, 875 animals killed before 1 December 2021). Two main ways for improving the current situation are offered for discussion:

- Application of effective animal protection measures

- Prompt removal of wolf individuals that have developed undesirable behavioural patterns from the wild.

Currently it has been observed that if animals are not kept in a herd, no protection against wolves is taken. If animals are kept in a herd, they are usually surrounded by a single-thread electrical fence and in singular cases by an electric net fence. The typical electric fence prevents herd animals from scattering; however, it is not an effective tool for keeping wolves outside of the territory. It is counterproductive to declare such tools as electric fences as effective ways of keeping wolves away from livestock. Farms that conduct commercial activities and receive income from livestock should be obliged to use protection tools and methods that are proven to be effective and ensure the safety of livestock.

During recent years, the formation of several 'hot-spots' have been observed. Damage cases were more frequent in those 'hot-spots' (Fig. 4). This indicates a typical pattern of wolf behaviour: hunt specialisation of particular individuals or families of wolves.

From 2015-2016 to 2018-2019 hunting seasons, the numbers of wolf hunting permits depended on districts: the wolf-hunting limit were higher in the districts in which the wolfinflicted damage was bigger). However, this did not yield any measurable results since the territory of a district is too big to eliminate specifically wolves that have developed negative behavioural patterns.

The law of Lithuania allows removal of wolf individuals from the wild even outside wolf hunting season. Such practice has its advantages and disadvantages. The first step should be improving the method, by which the approval of removal of a wolf from the wild outside hunting season is issued. The procedure itself is cumbersome, responsible municipal employees between various institutions and committees are not confident about it, and due to this the process becomes much longer. Receiving approval turns into a lengthy process, whereas it should be as prompt as possible once the necessary conditions are met. This would ensure the best results. As a tool, hunting an individual wolf is effective only if it is done immediately after the killing of livestock and in the site of the attack (or not further than $7 \mathrm{~km}$ from the attack location).

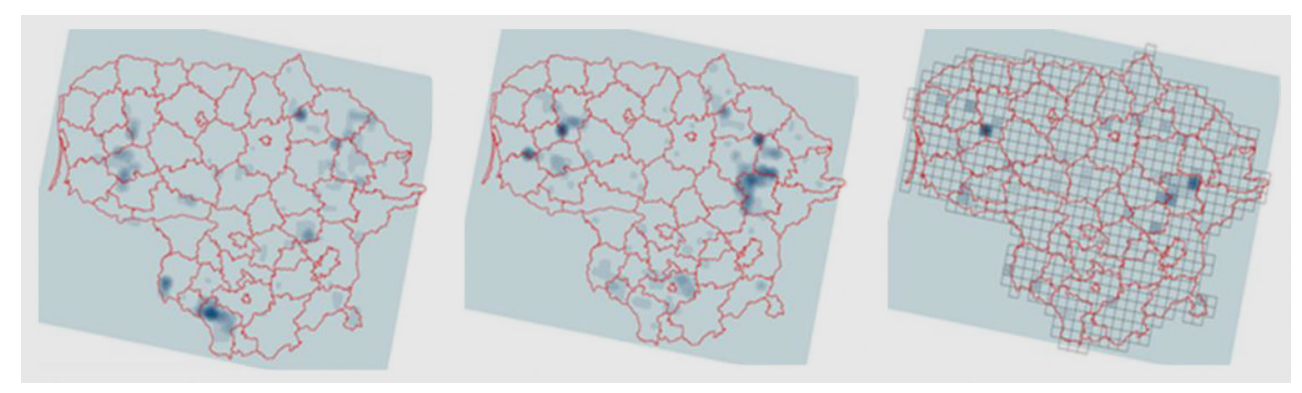

Fig. 4. Distribution of damage caused by wolves to livestock in the territory of Lithuania. 2019, 2020, and 2021 (before 1 September 2021). Kernel density analysis 


\section{CONCLUSIONS}

Most frequently, wolves attack sheep (60.167.4\% cases annually). Attacks in September were the most frequent (22.2\%), followed by October (19.2\%), and August (18.4\%).

The distribution of the inflicted damage across districts is not constant and changes from year to year; moreover, certain 'hotspots' were identified where attacks and damage done was recurrent.

Two main ways of improving the situation are the following: first, deploying effective livestock protection tools and methods, and, second, removing the wolves that have developed an undesirable behavioural pattern from the wild.

\section{FUNDING}

The study was conducted under the contract 'Wolf (Canis lupus) ecology researches' No. SREP-20-6 of the Research Council of Lithuania and Vytautas Magnus University.

Received 29 October 2021

Accepted 4 December 2021

\section{References}

1. Álvares F. Ecologia e conservação do lobo (Canis lupus L.) no noroeste de Portugal. PhD Thesis, Universidade de Lisboa, Portugal; 2011.

2. Andersone Ž . Summer nutrition of the wolf (Canis lupus) in the Nature Reserve Sliters, Latvia. Proceedings of the Latvian Academy of Sciences, Section B. 1998; 52: 79-80.

3. Balčiauskas L, Balčiauskienė L, Volodka $H$. Preliminary assessment of damage caused by the wolf in Lithuania. Acta Zoologica Lituanica. 2002; 12: 419-27.

4. Capitani C, Chynoweth M, Kusak J, Coban E, Sekercioglu C. Wolf diet in an agricultural landscape of north-eastern Turkey. Mammalia. 2016; 80: 329-34.
5. Carter NH, Linnell JDC. Co-adaptation is key to coexisting with large carnivores. Trends Ecol Evol. 2016; 31: 575-8.

6. Chapron G, Kaczensky P, Linnell JDC, von Arx M, Huber D, H. Andre, et al. Recovery of large carnivores in Europe's modern humandominated landscapes. Science. 2014; 346: 1517-9.

7. Ciucci P, Artoni L, Crispino F, Tosoni E, Boitani L. Inter-pack, seasonal and annual variation in prey consumed by wolves in Pollino National Park, southern Italy. Eur J Wildl Res. 2018; 64: 5.

8. De Marinis AM, Asprea A. Hair identification key of wild and domestic ungulates from southern Europe. Wildlife Bio. 2006; 12: 305-20.

9. Goszczynski J. Studies on the food of foxes. Acta Theriologica. 1974; 19: 1-18.

10. Iliopoulos Y, Sgardelis S, Koutis V, Savaris D. Wolf depredation on livestock in central Greece. Acta Theriol. 2009; 54: 11-22.

11. Jędrzejewski W, Schmidt K, Theuerkauf J, Jędrzejewska B, Selva N, Zub K, Szymura L. Kill rates and predation by wolves on ungulate populations in Białowieża Primeval Forest (Poland). Ecology. 2002; 83: 1341-56.

12. Litvaitis JA, Titus K, Anderson EM. Measuring vertebrate use of terrestrial habitats and foods. In: Research and Management Techniques for Wildlife and Habitats. TA. Bookhout, ed. Bethesda; 1996; 254-74.

13. Llaneza L, López-Bao JV. Indirect effects of changes in environmental and agricultural policies on the diet of wolves. Eur J Wildl Res. 2015; 61: 895-902.

14. Lockie JD. The estimation of the food of foxes. J Wildl Manag. 1959; 23: 224-7.

15. Newsome TM, Boitani L, Chapron G, Ciucci P, Dickman CR, Dellinger JA, Lòpez-Bao JV, Peterson RO, Shores CR, Wirsing AJ, Ripple WJ. Food habits of the world's grey wolves. Mammal Rev. 2016; 46: 255-69.

16. Nowak S, Mysłajek RW. Livestock Guarding Dogs in the Western Part of the Polish 
Carpathians. Carnivore Damage Prevention News, January. 2004; 13-7.

17. Nowak S, Mysłajek RW. Poradnik ochrony zwierzą hodowlanych przed wilkmi. Stowarzyszenie dla Natury Wilk, Twardorzeczka, 2006, 68 p.

18. Nowak S, Mysłajek RW, Jędrzejewska B. Patterns of wolf Canis lupus predation on wild and domestic ungulates in the Western Carpathian Mountains (S Poland). Acta Theriologica. 2005; 50: 263-76.

19. Petridou M, Youlatos D, Lazarou Y, Selinides K, Pylidis Ch, Giannakopoulos A, Kati V, Iliopoulos Y. Wolf diet and livestock selection in central Greece. Mammalia. 2019; 83: 530-8.

20. Špinkytè-Bačkaitienè R. The influence of environmental factors on the population of wolves (Canis lupus lupus L.) in Lithuanian forests. Dissertation. Kaunas, 2012, 114 p. (in Lithuanian language).

21. Teerink BJ. Hairs of West European mammals. Cambridge University Press, 1991, 224 p.

22. Torres RT, Silva N, Brotas G, Fonseca C. To eat or not to eat? The diet of the endangered Iberian wolf (Canis lupus signatus) in a human-dominated landscape in central Portugal. PLoS One, 2015; 10: e0129379.

23. Trbojević I, Penezić A, Kusak J, Stevanović O, Ćirović D. Wolf diet and livestock depredation in North Bosnia and Herzegovina. Mamm Biol. 2020; 100: 499-504.

24. Valdmann H, Koppa O, Looga A. Diet and prey selectivity of wolf Canis lupus in middleand south-eastern Estonia. Baltic Forestry. 1998; 4: 42-7.
Renata Špinkytė-Bačkaitienė, Petras Adeikis

\section{NAMINIŲ GYVULIŲ IR AUGINTINIŲ DALIS VILKŲ MITYBOJE LIETUVOJE}

\section{Santrauka}

Vilkai daro nemažą žalą naminiams gyvuliams, todèl ūkininkai reikalauja mažinti vilkų populiaciją. Nevyriausybinès aplinkosaugos organizacijos tam prieštarauja, ir visuomenejje kyla socialine ittampa. Žalos gyvulininkystei dèsningumai buvo nagrinèti pasitelkus Valstybinès saugomų teritorijų tarnybos prie Aplinkos ministerijos Biologinès ìvairovès duomenų bazejje (BIDB) nuo $2019 \mathrm{~m}$. sausio $1 \mathrm{~d}$. iki $2021 \mathrm{~m}$. gruodžio $1 \mathrm{~d}$. registruotus duomenis. Vilkų mityba analizuota pagal sumedžiotų individų skrandžių turinị ir aukų likučius ekskrementuose $(n=132)$. Tyrimų laikotarpiu BIDB buvo registruoti 1139 atvejai, kai vilkai užpuolè naminius gyvūnus. Dažniausiai vilkai užpuldavo avis, ir tai sudarè 60,1-67,4 \% visų užpuolimo atvejų kasmet. Iš viso 2019 m. užregistruoti 1167 papjauti gyvuliai, 2020 m. - 1279, o 2021 m. (iki gruodžio 1 d.) - 875 papjauti gyvuliai. Minimu laikotarpiu BIDB užregistruoti 28 atvejai apie vilkų papjautus naminius šunis. Remiantis vilkų mitybos tyrimų medžiaga, surinkta iš maisto likučių vilkų skrandžiuose ar ekskrementuose, naminių gyvūnų likučiai rasti 6,82\% tirtų pavyzdžių.

Raktažodžiai: vilkas, mityba, naminiai gyvuliai, šuo, žala, žalos atvejai 